\author{
${ }^{[0000-0001-9241-1760] ~ Н . ~ В . ~ Ф і л і м о н о в а, ~}$ к.m.н., \\ [0000-0003-1727-3286] С. О. Філімонов, к.т.н., доиент,

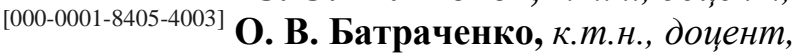 \\ В. В. Орел, студент \\ Черкаський державний технологічний університет \\ б-р Шевченка, 460, м. Черкаси, 18006, Україна
}

\title{
ВПЛИВ ОБРОБКИ ТИСКОМ НА СТРУКТУРНО-МЕХАНІЧНІ ТА ОРГАНОЛЕПТИЧНІ ВЛАСТИВОСТІ ГОТОВИХ КОВБАСНИХ ВИРОБІВ
}

Для подальшого ефективного розвитку та, відповідно, ефективної експлуатаиії такого виду технологічного обладнання, як вовчки, актуальним є вироблення достовірних рекомендаиій щодо параметрів впливу робочих органів вовчків на готові ковбасні вироби. Досліджувалися структурно-механічні й органолептичні властивості ковбасних виробів з таких видів сировини: яловичина, оброблена в м'ясорубиі, яловичина, подрібнена на кубики ножем вручну, а також піддана обробиі тиском. Встановлено, щя найбільший модуль осьового стискання властивий ковбасам із яловичини, нарізаної кубиками (285 кПа). Для виробів з сировини, обробленої тиском у 0,4 МПа та у 0,6 МПа, а також з м'ясного фаршу модуль осьового стискання набуває суттєво менших значень (249 кПа, 217 кПа та 140 кПа відповідно). Найбільше напруження стандартної пенетрачї̈ також спостерігається для ковбас з яловичини, нарізаної кубиками (124 кПа), тоді як для продуктів з сировини, яка оброблена тиском у 0,4 МПа та у 0,6 МПа, а також для м'ясного фаршу - 96 кПа, 87 кПа та 71 кПа відповідно. Залежність напруження зрізу ковбас від виду обробки сировини аналогічна напруженню стандартної пенетрації. Отримані результати дають змогу вважати обробку м'яса тиском у вовчках позитивним процесом, необхідним для отримання ковбасних виробів із високими органолептичними властивостями

Ключові слова: м'ясорізальний вовчок, м'ясо, тиск, фарш, структурно-механічні властивості, органолептика.

Вступ. Кількісні та якісні показники виготовлених у промислових умовах ковбасних виробів суттєвим чином залежать від ефективності процесу подрібнення м'ясної сировини. I якщо для споживача багато 3 цих показників залишаються поза увагою, то органолептичні властивості продукту часто виступають на перший план. У спеціалізованих літературних джерелах $[1,2]$ вказується на актуальність всебічного зменшення стискання м'ясної сировини при подрібненні в м'ясорубках великої і малої продуктивності з метою зменшення втрат м'ясного соку та підвищення соковитості готового продукту.

Однак подрібнення м'яса на вовчках до стану фаршу, за попередніми дослідженнями авторів статті, приводить не лише до зменшення розмірів шматочків сировини, а й до покращення їх органолептичних властивостей завдяки підвищенню м'якості та ніжності консистенції. Зважаючи на це, обгрунтованим $\epsilon$ припущення про позитивну роль обробки тиском м'ясної сировини при подрібненні у вовчках.

Для подальшого ефективного розвитку та, відповідно, ефективної експлуатації такого виду технологічного обладнання, як вовчки актуальним $\epsilon$ вироблення достовірних рекомендацій щодо параметрів впливу робочих органів вовчків на м'ясну сировину. Вирішенню саме цього завдання і присвячена ця робота.

Аналіз останніх джерел. У роботах [38] наведено результати дослідження робочих процесів у вовчках. Однак в них, як і в інших відомих роботах, не наведено даних про вплив прикладеного тиску на органолептичні та структурно-механічні властивості отримуваного фаршу чи готового продукту. Незважаючи на численні дослідження [9-15] реологічних властивостей м'яса та м'ясних напівфабрикатів, нині відсутні вичерпні відомості щодо впливу обробки тиском м'яса на означені властивості. Доцільним $є$ дослідження 
модуля осьового стискання $\mathrm{E}$, напруження стандартної пенетрацї $\Theta_{\text {пен}}$, напруження зрізу $\Theta_{\text {зр }}$ та органолептичних властивостей ковбас 3 різних видів м'ясної сировини за умов відсутності та наявності обробки їі тиском.

Метою роботи $\epsilon$ встановлення характеру впливу обробки м'ясної сировини тиском на структурно-механічні та органолептичні властивості готових ковбасних виробів.

Виклад основного матеріалу. Досліджувалися структурно-механічні (CMB) та органолептичні властивості ковбасних виробів 3 м'ясної сировини, переробленої в м’ясорубці, та після подрібнення м'яса на кубики ножем вручну. Об’єктами досліджень були ковбаси 3 таких видів сировини (рисунок 1):

- м'ясний фарш 3 яловичини вищого гатунку, отриманий при подрібненні крізь решітку м’ясорубки з отворами діаметром 5 мм;

- яловичина, нарізана ножем на кубики зі стороною 5 мм (ЯНК);

- ЯНК, яка була піддана дії тиску стискання $\mathrm{P}_{\text {ст }}=0,4$ МПа (відповідно до [10] в різальному вузлі вовчка виникають тиски близько 0,05-0,8 МПа залежно від маси шматків вихідної сировини та залежно від гостроти різального інструменту вовчка);

- ЯНК, яка була піддана дії тиску стискання $\mathrm{P}_{\mathrm{cт}}=0,6 \mathrm{MПа.}$

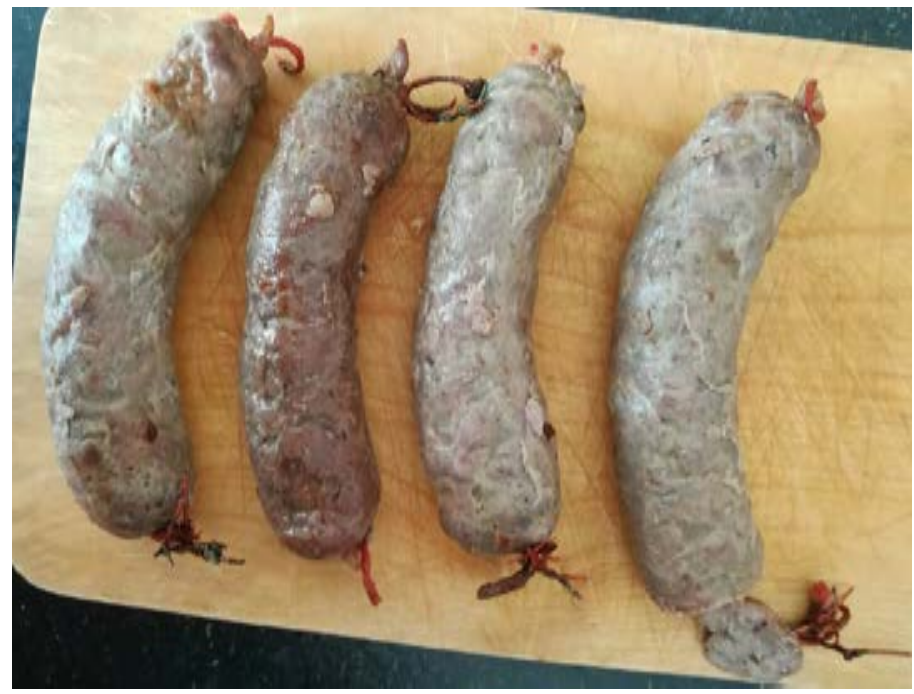

a)

б)

B)

г)

а) 3 м'ясного фаршу; б) з яловичини, нарізаної кубиками;

в) з яловичини, нарізаної кубиками та підданої дії тиску $\mathrm{P}_{\mathrm{cr}}=0,4 \mathrm{MПа;}$

г) з яловичини, нарізаної кубиками та підданої дії тиску $\mathrm{P}_{\text {ст }}=0,6 \mathrm{MПа}$

Рисунок 1 - Загальний вигляд досліджуваних видів ковбас, які виготовлені 3 різної сировини

Обробка виробів тиском полягала у розміщенні шматків ковбас між опорою і натискною плитою і у наступному встановленні вантажу масою $\mathrm{m}$ на натискну плиту (рисунок 2 ). Після 10 с дії тиску виріб розвантажувався і підлягав вимірюванню СМВ та органолептичних властивостей.

Значення прикладеного тиску визначалося за відомим виразом

$$
P_{C T}=\frac{m \cdot g}{S},
$$

де $m$ - маса вантажу, кг; g - прискорення вільного падіння, g=9,81 м/ $\mathrm{c}^{2}$; $S$ - площа, на якій розміщена порція сировини, $\mathrm{M}^{2}$.

Для визначення СМВ ковбас використовувалася модифікована електромеханічна універсальна випробувальна машина SANS СMT2503 лабораторії м'ясних продуктів Інституту продовольчих ресурсів НААН України (м. Київ). Універсальна випробувальна машина SANS CMT2503 (рисунок 3) призначена для визначення міцнісних та структурномеханічних властивостей різних матеріалів. 


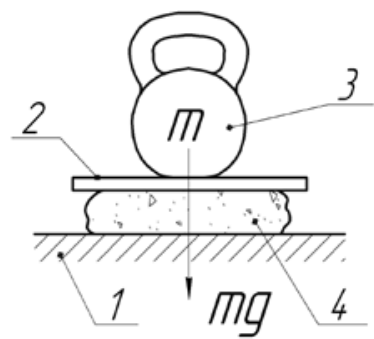

1 - опора; 2 - натискна плита; 3 - вантаж;

4 - м'ясна сировина

Рисунок 2 - Схема обробки м'ясної сировини тиском

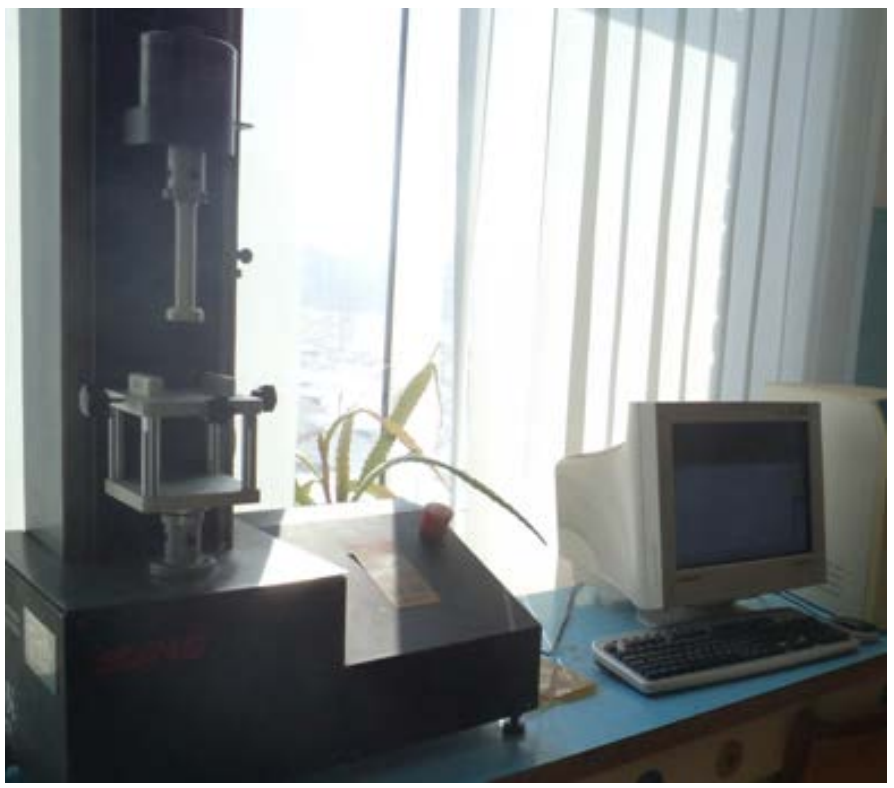

a)

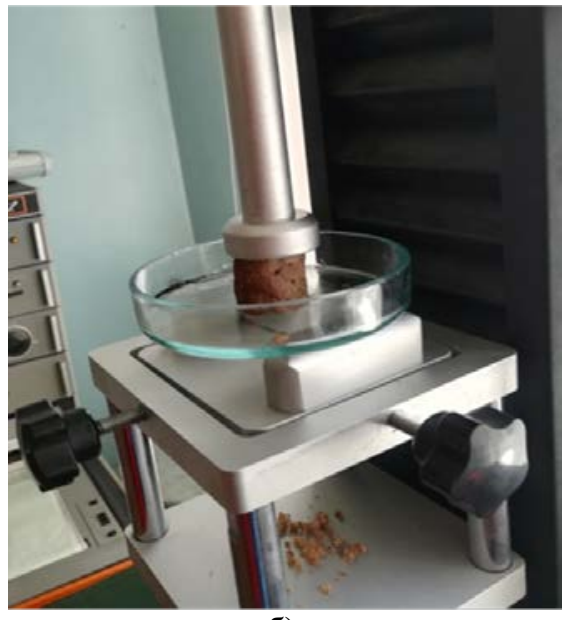

б)

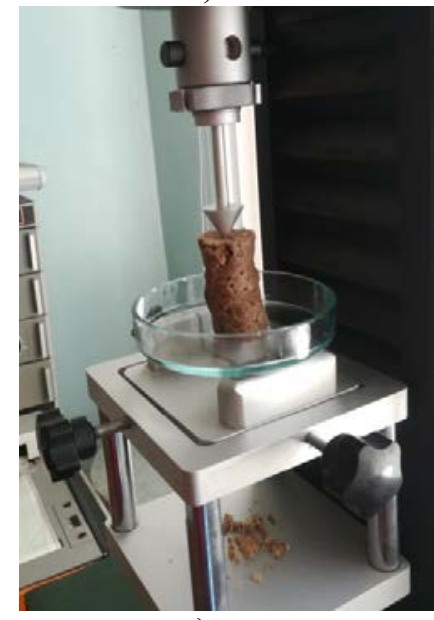

B)

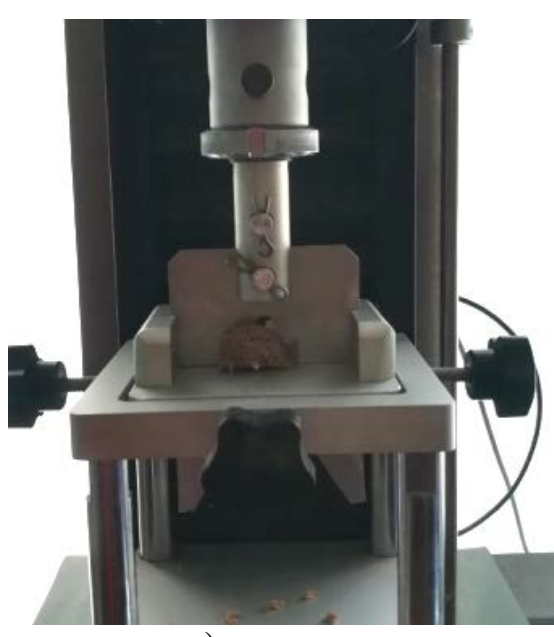

г)

а) загальний вигляд; б) вимірювання модуля осьового стискання для виробу з ЯНК;

в) вимірювання модуля осьового стискання для ковбаси з ЯНК, яка була піддана дії тиску стискання $\mathrm{P}_{\mathrm{cr}}=0,4 \mathrm{MПа;} \mathrm{г)} \mathrm{вимірювання} \mathrm{зусилля} \mathrm{зрізу} \mathrm{для} \mathrm{ковбаси} \mathrm{з} \mathrm{ЯНК,} \mathrm{яка} \mathrm{була} \mathrm{піддана} \mathrm{дії} \mathrm{сили} \mathrm{тиску} \mathrm{0,4} \mathrm{МПа}$

Рисунок 3 - Універсальна випробувальна машина SANS CMT2503

В ній використовується принцип замкненої цифрової системи керування та вимірювань із застосуванням комп'ютера, на дисплей якого виводиться необхідна інфор- мація у цифровому або графічному вигляді. При цьому результати випробувань автоматично обробляються та зберігаються в пам'яті системи.

( ) Н. В. Філімонова, С. О. Філімонов, О. В. Батраченко, В. В. Орел, 2019 DOI: 10.24025/2306-4412.3.2019.182503 
Визначались модуль осьового стискання Е, напруження стандартної пенетрації $\Theta_{\text {пен }}$ та напруження зрізу $\Theta_{3 р}$ сировини. Використовувалися такі насадки з інденторами: циліндричний плунжер - для визначення Е; індентор Magness-Teylor - для визначення $\Theta_{\text {пен }}$; ніж 3 кутовим вирізом - для визначення напружен-

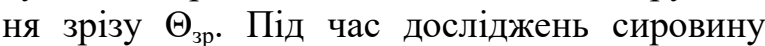
встановлювали під індентор в циліндричній кюветі під траверсою машини, центруючи відносно індентора, після чого вмикали привод. Швидкість руху індентора була $1,67 \cdot 10^{-4} \mathrm{M} / \mathrm{c}$ при визначенні Е та $3,33 \cdot 10^{-4} \mathrm{M} / \mathrm{c}$ при визначенні $\Theta_{\text {пен }}$

Модуль осьового стискання визначався за виразом:

$$
E=\frac{P}{S_{0}} \cdot \frac{h_{0}}{h_{1}}, \text { Па, }
$$

де $P$ - зусилля стискання, Н (визначається на прямолінійній ділянці кривої «навантаженнядеформація»);

$S_{0}$ - початкова площа перерізу зразка, м $^{2}$;

$h_{0}$ - початкова висота зразка, м;

$h_{1}$ - висота зразка після стискання, м.

Напруження стандартної пенетрації визначалося за формулою П. О. Ребіндера:

$$
\Theta_{\text {пен }}=k_{\alpha} \cdot \frac{P}{h^{2}}, \text { Па, }
$$

де $P$ - зусилля пенетрації, Н (визначається на прямолінійній ділянці кривої «навантаженнядеформація»);

$h$ - глибина занурення конуса, м;

$k_{\alpha}$ - константа конуса (при $\alpha=60^{\circ} k_{\alpha}=0,214$ ).

Напруження зрізу визначалося таким чином:

$$
\Theta_{3 p}=\frac{P}{S}, \text { Па, }
$$

де $P$ - зусилля зрізу, Н (визначається на прямолінійній ділянці кривої «навантаженнядеформація»);

$S$ - площа зрізу, м $^{2}$

Органолептичний аналіз проводився згідно з ДСТУ 4823.1:2007 «Продукти м’ясні. Органолептичне оцінювання показників якості. Частина 1. Терміни та визначення понять» та згідно 3 ДСТУ 4823.2:2007 «Продукти м'ясні. Органолептичне оцінювання показників якості. Частина 2. Загальні вимоги». Визначалася цілісність структури шматочків виробів і здатність шматочків м'яса до розшарування на окремі волокна та на пучки волокон при розтиранні шматочків пальцями.

Отримані результати визначення структурно-механічних та органолептичних властивостей сировини наведено в таблиці 1.

Таблиця 1 - Структурно-механічні та органолептичні властивості ковбас

\begin{tabular}{|l|l|c|c|c|c|}
\hline № & \multicolumn{4}{|c|}{ Властивості сировини } \\
\cline { 3 - 6 } & $\begin{array}{c}\text { Вид м'ясної сировини } \\
\text { (консистенція) }\end{array}$ & $\begin{array}{c}\text { Модуль } \\
\text { осьового } \\
\text { стискання } \\
\text { Е, кПа }\end{array}$ & $\begin{array}{c}\text { Напруження } \\
\text { стандартної } \\
\text { пенетрації } \\
\Theta_{\text {пен, } \text { кПа }}\end{array}$ & $\begin{array}{c}\text { Напруження } \\
\text { зрізу } \Theta_{3 р}, \text { кПа }\end{array}$ & $\begin{array}{c}\text { Органолептична } \\
\text { оцінка }\end{array}$ \\
\hline 1 & ЯНК & 285 & 124 & 133 & 3,1 \\
\hline 2 & ЯНК, $\mathrm{P}_{\mathrm{cr}}=0,4 \mathrm{MПа}$ & 249 & 96 & 104 & 3,6 \\
\hline 3 & ЯНК, $\mathrm{P}_{\mathrm{cr}}=0,6 \mathrm{MПа}$ & 217 & 87 & 89 & 4,2 \\
\hline 4 & М'ясний фарш & 140 & 71 & 68 & 4,7 \\
\hline
\end{tabular}

Встановлено, що ковбасні вироби 3 м'ясного фаршу після подрібнення в м'ясорубці мають значно м'якшу консистенцію і кращі органолептичні властивості порівняно $з$ ковбасами, виготовленими з ЯНК. При органолептичних дослідженнях виробу з фаршу шматочки розпадалися на окремі волокна та на пучки волокон. Вироби з ЯНК, які були піддані обробці тиском, наближаються за своїми СМВ до ковбас із м'ясного фаршу у міру збільшення значення тиску. Однак навіть при тиску Рст=0,6 МПа їх структурно-механічні та органолептичні властивості не досягають еталонних значень.

Висновки. Експериментальним шляхом досліджено структурно-механічні та органолептичні властивості ковбасних виробів 3 м'ясної сировини, яка переробляється у вовчках. Встановлено, що найбільший модуль осьового стискання властивий виробу з яловичини, яка нарізана кубиками (285 кПа). Для виробів $з$ такої ж сировини, яка оброблена (C) Н. В. Філімонова, С. О. Філімонов, О. В. Батраченко, В. В. Орел, 2019 DOI: DOI: 10.24025/2306-4412.3.2019.182503 
тиском у 0,4 МПа та у 0,6 МПа, а також із м'ясного фаршу модуль осьового стискання набуває суттєво менших значень (249 кПа, 217 кПа, 140 кПа відповідно). Найбільше напруження стандартної пенетрації також спостерігається для виробів 3 яловичини, яка нарізана кубиками (124 кПа), тоді як для виробів 3 такої ж сировини, яка оброблена тиском у 0,4 МПа та у 0,6 МПа, а також для м'ясного фаршу - 96 кПа, 87 кПа, 71 кПа відповідно.

Можна зробити висновок, що саме вплив тиску при подрібненні м'яса у вовчках і м'ясорубках визначає ніжну консистенцію фаршу та готових ковбасних виробів з нього. Отримані результати дають змогу стверджувати, що з точки зору технології виготовлення ковбас м'ясний фарш - це м'ясо, яке нарізане та роздавлене. Нарізане м'ясо (кубики, отримані на дайсері чи шпигорізці) не дає можливості досягти еталонних показників готових ковбасних виробів.

Отримані результати, на відміну від відомих уявлень, дають змогу вважати обробку м'яса тиском у вовчках позитивним процесом, необхідним для отримання ковбасних виробів 3 високими органолептичними властивостями. Для зменшення втрат м'ясного соку при цьому доцільною $\epsilon$ розробка нових методів подрібнення м'ясної сировини, які передбачають iii обробку тиском.

Подальші дослідження в цьому напрямі дадуть можливість визначити нові шляхи вдосконалення обладнання для подрібнення м'яса.

\section{Список літератури}

[1] В. И. Ивашов, Новое в конструировании волчков: обзор информ. Москва: АгроНИИТЭИММП, 1988.

[2] О. I. Некоз, та О. В. Батраченко, Проектування м'ясорізальних вовчків: навч. посіб.; М-во освіти і науки України, Черкас. держ. технол. ун-т. Черкаси: ЧДТУ, 2014.

[3] В. К. Бубыренко, "Исследование волчков с целью повышения их эффективности и долговечности рабочих органов", автореф. дис. канд. техн. наук. МТИММП, Москва, 1977.

[4] В. В. Горяев, "Совершенствование конструкций и методики расчета режущего механизма волчков", автореф. дис. канд. техн. наук, Москва, 1989.

[5] Д. А. Максимов, "Разработка адаптированного гибкого подающего рабочего органа в волчках": автореф. дис. канд. техн. наук, Москва, 2008.

[6] О.В.Батраченко, "Підвищення ефективності роботи та довговічності м'ясорізальних машин", дис. канд. техн. наук: 05.18.12, Вінниця, 2014.

[7] Н. В. Філімонова, "Підвищення ефективності роботи вовчків шляхом узгодження подачі та процесу подрібнення м'ясної сировини": дис. канд. техн. наук: 05.18.12, Харків, 2017.

[8] А. С. Андрианов, Г. А. Мартынов, и Г. Н. Крючков, "Определение динамических нагрузок волчка", Мясная индустрия СССР, № 5, с. 32-34, 1981.

[9] Н. В. Філімонова, "Дослідження структурно-механічних властивостей м'яса як об'єкта переробки у вовчку", Вісник Хмельницького національного університету, № 4, c. 25-31, 2015.

[10] E. Haack, und W. Schnackel, "Kombinationsmöglichkeiten quasi unbegrenzt - Trennsysteme zur Aufwertung stofflicher Eigenschaften von Fleisch", Teil 1, Fleischwirtschaft, Nu. 3, S. 49-54, 2008.

[11] W. Schnackel, and J. Krickmeier, Oktaviani. "Determination of meat cutting properties through the analysis of Warner Bratzler curve - Investigations on beef, pork and back fat under chilled temperature and low speed for energy saving", Fleischwirtschaft International, no. 4, pp. 56-61, 2011.

[12] W. Schnackel, J. Krickmeier, Oktaviani, W. Pongjanyanukul, and D. Schnackel, "Modelling of mincing processes by determination of meat cutting properties through the analysis of Warner Bratzler curve", Tagungsband 57th Int. Congress of Meat Science and Technology. Ghent, 2011, p. 268.

[13] W. Schnackel, J. Krickmeier, Oktaviani, D. Schnackel, und I. Micklisch, "Untersuchungen zur optimierung des wolfprozesses", Teil 1, Fleischwirtschaft, Nu. 7, S. 83-87, 2011.

[14] W. Schnackel, J. Krickmeier, W. Pongjanyanukul, D. Schnackel, I. Micklisch, und O. Haack, "Untersuchungen zur optimierung

( С Н. В. Філімонова, С. О. Філімонов, О. В. Батраченко, В. В. Орел, 2019 DOI: $10.24025 / 2306-4412.3 .2019 .182503$ 
des wolfprozesses", Teil 4, Fleischwirtschaft, Nu. 7, S. 91-96, 2012.

[15] W. Schnackel, Oktaviani, and J. Krickmeier, "Determination of beef and pork cutting properties through the analysis of Warner Bratzler curve", in Sci. Conf. with Int. Participation Food Science, Engineering and Technologies 2010: proceedings, Plovdiv, October 15-16, vol. LVII, iss. 1, pp. 103108, 2010.

\section{References}

[1] V. I. Ivashov, The new in meat comminutors construction: inform. survey. Moscow: AgroNIITEIMMP, 1988 [in Russian].

[2] O. I. Nekoz, and O. V. Batrachenko, Designing of meat-cutting comminutors: textbook, Ministry of Education and Science of Ukraine, Cherkasy State Technol. un-ty, Cherkasy: ChDTU, 2014 [in Ukrainian].

[3] V. K. Bubyrenko, "Meat comminutors study aining at the increase of their efficiency and durability of operating elements", M.S. thesis in Eng., MTIMMP, Moscow, 1977 [in Russian].

[4] V. V. Ghorjaev, "Improvement of constructions and the technique for calculating the cutler bar of meat comminutors", M.S. thesis in Eng., Moscow, 1989 [in Russian].

[5] D. A. Maksimov, "Development of adapted flexible feed operating element in meat comminutors", M.S. thesis in Eng., Moscow, 2008 [in Russian].

[6] O. V. Batrachenko, "Increase of the efficiency and durability of meat-cutting machines", M.S. thesis in Eng.: 05.18.12, Vinnytsia, 2014 [in Ukrainian].

[7] N. V. Filimonova, "Increase of meat comminutors efficiency by coordination of feeding and mincing of meat raw material", M.S. thesis in Eng.: 05.18.12, Kharkiv, 2017 [in Ukrainian].

[8] A. S. Andrianov, G. A. Martynov, and G. N. Kriuchkov, "Determination of meat comminutor's dynamic loads", Miasnaia industryia SSSR, no. 5, pp. 32-34, 1981 [in Russian].

[9] N. V. Filimonova, "Study of structural and mechanical properties of meat as an object of processing in meat comminutors", Visnyk Khmelnytskoho natsionalnoho universytetu, no. 4, pp. 25-31, 2015 [in Ukrainian].

[10] E. Haack, und W. Schnackel, "Kombinationsmöglichkeiten quasi unbegrenzt - Trennsysteme zur Aufwertung stofflicher Eigenschaften von Fleisch", Teil 1, Fleischwirtschaft, Nu. 3, S. 49-54, 2008.

[11] W. Schnackel, and J. Krickmeier, Oktaviani. "Determination of meat cutting properties through the analysis of Warner Bratzler curve - Investigations on beef, pork and back fat under chilled temperature and low speed for energy saving", Fleischwirtschaft International, no. 4, pp. 56-61, 2011.

[12] W. Schnackel, J. Krickmeier, Oktaviani, W. Pongjanyanukul, and D. Schnackel, "Modelling of mincing processes by determination of meat cutting properties through the analysis of Warner Bratzler curve", Tagungsband 57th Int. Congress of Meat Science and Technology. Ghent, 2011, p. 268.

[13] W. Schnackel, J. Krickmeier, Oktaviani, D. Schnackel, und I. Micklisch, "Untersuchungen zur optimierung des wolfprozesses", Teil 1, Fleischwirtschaft, Nu. 7, S. 83-87, 2011.

[14] W. Schnackel, J. Krickmeier, W. Pongjanyanukul, D. Schnackel, I. Micklisch, und O. Haack, "Untersuchungen zur optimierung des wolfprozesses", Teil 4, Fleischwirtschaft, Nu. 7, S. 91-96, 2012.

[15] W. Schnackel, Oktaviani, and J. Krickmeier, "Determination of beef and pork cutting properties through the analysis of Warner Bratzler curve", in Sci. Conf. with Int. Participation Food Science, Engineering and Technologies 2010: proceedings, Plovdiv, October 15-16, 2010, vol. LVII, iss. 1, pp. 103-108. 
N. V. Filimonova, $P h . D$.,

S. O. Filimonov, $P$ h. D., associate professor,

O. V. Batrachenko, Ph. D., associate professor,

V. V. Orel, student

Cherkasy State Technological University,

Shevchenko blvd, 460, Cherkasy, 18006, Ukraine

\section{INFLUENCE OF PRESSURE PROCESSING ON STRUCTURAL, MECHANICAL AND ORGANOLEPTIC PROPERTIES OF SAUSAGE PRODUCTS}

For further efficient development and, accordingly, efficient operation of such type of technological equipment, as meat comminutors, it is urgent to make reliable recommendations on the parameters of the influence of meat comminutors working organs on raw materials and prepared sausage products. Structural, mechanical and organoleptic properties of sausage products from such raw materials as: beef processed in a meat grinder, beef minced by hand with a knife and beef processed with a pressure have been studied. It is established that the largest module of axial compression is peculiar to beef sausages minced with a knife (285 $\mathrm{kPa}$ ). For products from raw materials processed with a pressure of 0.4 MPa and 0.6 MPa, as well as minced meat, the axial compression module accepts significantly smaller values (249 kPa, $217 \mathrm{kPa}$ and $140 \mathrm{kPa}$, respectively). The highest standard penetration pressure is also observed for beef sausages, cut into cubes (124 kPa), while for the products from raw materials processed with a pressure of 0,4 MPa and 0,6 MPa, as well as for minced meat it is $96 \mathrm{kPa}, 87 \mathrm{kPa}$ and $71 \mathrm{kPa}$ respectively. The results obtained allow to consider the processing of meat with a pressure in meat comminutors as a positive process necessary for obtaining sausage products with high organoleptic properties. The impact of the pressure when grinding meat in a meat grinder defines the delicate consistency of the meat and finished sausage products. Sliced meat doesn't allow to achieve benchmarks of finished sausage products. It is necessary to supplement the definition of "mince" to read as follows: "mince is meat, sliced and crushed." A purely compressive pressure, which corresponds to the pressure in the working chamber of meat grinder, doesn't lead to the acquisition of raw materials, cut into cubes, the reference values of structural, mechanical and organoleptic properties. It is reasonable to study the effect of joint action of compressive and shear stresses on the indicated properties of the raw material. The meat processing with a pressure in meat comminutors should be considered a positive process necessary to obtain sausages with high organoleptic properties. To reduce losses of meat juice during the raw material processing it is appropriate to develop new methods which provide for its processing by pressure.

Keywords: meat grinder, meat, pressure, mince, rheological properties.

Стаття надійшла 29.08.2019

Прийнято 13.09.2019

(c) Н. В. Філімонова, С. О. Філімонов, О. В. Батраченко, В. В. Орел, 2019 DOI: $10.24025 / 2306-4412.3 .2019 .182503$ 